\title{
Pengaruh penambahan proporsi tepung wortel (Daucus carota $L$.) dan lama pendinginan terhadap kualitas mikrobiologi bakso daging ayam
}

\author{
The effect of adding the proportion of carrot flour (Daucus carota L.) and cooling time \\ to the microbiological quality of chicken meatball \\ Andik Dwi Purnomo $^{1}{ }^{*}$, Muh. Aniar Hari Swasono ${ }^{1)}$ \\ ${ }^{1}$ Prodi Ilmu Teknologi Pangan, Universitas Yudharta Pasuruan, Jawa Timur \\ *Email : andikovic.adp@gmail.com \\ Informasi artikel \\ Diterima: 07/08/2020; ditinjau: 08/08/2020; disetujui: 03/09/2020
}

\begin{abstract}
This study aims to determine the effect of adding the proportion of carrot flour and cooling time on the microbiological quality of chicken meatballs and to determine the proportion of the best carrot flour added to chicken meatballs on microbiological and organoleptic quality. The method used in this research was randomized block design (RAK), which had 2 treatments, namely the addition of carrot flour to tapioca flour $(0 \%, 25 \%, 50 \%$ and $75 \%)$ and cooling time (3 days and 5 days). The tests carried out included microbiology ( $\mathrm{pH}$, total plate count, total coliform, total yeast and mold) and organoleptic tests (taste, color, aroma, texture). The data obtained were analyzed using ANOVA statistical analysis using Minitab software and followed by the Tuckey difference test, while the organoleptic parameters were analyzed using the Fridmen test. The results of the study based on microbiological tests showed the best treatment according to the Zeleny method in L1W3 treatment (3 days cooling time; $25 \%$ tapioca flour: $75 \%$ carrot flour). The results of microbiological research showed that with $\mathrm{pH}$ (6.55), total plate count $\left(0,12 \log 10^{2} \mathrm{cfu} / \mathrm{gr}\right)$, total coliform $\left(0.03 \log 10^{2} \mathrm{cfu} / \mathrm{gr}\right)$, total yeast and molds $\left(0.17 \log 10^{2} c f u / g r\right)$, and organoleptic taste 2.72 (neutral), aroma 2.92 (neutral), color 3,08 (neutral) and texture 3 (neutral). The results of the study based on the Organoletic test showed that the best treatment was in the L1W1 treatment ( 3 days cooling time; $75 \%$ tapioca flour: $25 \%$ carrot flour) the results of organoleptic research showed that with the provisions of $\mathrm{pH}(6.55)$, total plate count $\left(1.43 \log 10^{2} \mathrm{cfu} / \mathrm{gr}\right)$, total coliform (1.15 $\log 10^{2} \mathrm{cfu} / \mathrm{gr}$ ), total yeast and mold (2.33 log $\left.10^{2} \mathrm{cfu} / \mathrm{gr}\right)$, and organoleptic taste 3 (neutral), aroma 3.96 (like), color 3.64 (like) and textures 2.32 (disliked).
\end{abstract}

Keywords: meatballs, carrot flour, chicken meat

\begin{abstract}
ABSTRAK
Penelitian ini bertujuan untuk mengetahui pengaruh penambahan proporsi tepung wortel dan lama pendinginan terhadap kualitas mikrobiologi bakso daging ayam dan mengetahui proporsi tepung wortel terbaik yang ditambahkan pada bakso ayam terhadap kualitas mikrobiologi dan organoleptik. Metode yang digunakan dalam penelitian bakso daging ayam yaitu rancangan acak kelompok (RAK), memiliki 2 perlakuan yaitu penambahan tepung wortel terhadap tepung tapioka $(0 \%, 25 \%, 50 \%$ dan $75 \%$ ) dan lama pendinginan (3 hari dan 5 hari). Uji yang dilakukan meliputi mikrobiologi $(\mathrm{pH}$, total plate count, total coliform, total khamir dan kapang) dan uji organoleptik (rasa, warna, aroma, tekstur). Data yang diperoleh dilakukan analisis
\end{abstract}


statistik Anova menggunakan software minitab dan dilanjutkan dengan uji beda Tuckey, sedangkan parameter organoleptik dilakukan analisis statistik menggunakan uji Fridmen. Hasil dari penelitian berdasarkan uji mikrobiologi menunjukkan perlakuan terbaik menurut metode Zeleny pada perlakuan L1W3 (lama pendinginan 3 hari; tepung tapioka $25 \%$ : tepung wortel $75 \%$ ) hasil penelitian mikrobiologi menunjukkan dengan ketentuan $\mathrm{pH}(6,55)$, total plate count $\left(0,12 \log 10^{2} \mathrm{cfu} / \mathrm{gr}\right)$, total coliform $(0,03$ $\left.\log 10^{2} \mathrm{cfu} / \mathrm{gr}\right)$, total khamir dan kapang $\left(0,17 \log 10^{2} \mathrm{cfu} / \mathrm{gr}\right)$, dan organoleptik rasa 2,72 (netral), aroma 2,92 (netral), warna 3,08 (netral) dan tekstur 3 (netral). Hasil dari penelitian berdasarkan uji Organoletik menunjukkan perlakuan terbaik terdapat pada perlakuan L1W1 (lama pendinginan 3 hari; tepung tapioka 75\%: tepung wortel 25\%) hasil penelitian organoleptic menunjukkan dengan ketentuan $\mathrm{pH}(6,55)$, total plate count $\left(1,43 \log 10^{2} \mathrm{cfu} / \mathrm{gr}\right)$, total coliform $\left(1,15 \log 10^{2} \mathrm{cfu} / \mathrm{gr}\right)$, total khamir dan kapang $\left(2,33 \log 10^{2} \mathrm{cfu} / \mathrm{gr}\right.$ ), dan organoleptik rasa 3 (netral), aroma 3,96 (suka), warna 3,64 (suka) dan tekstur 2,32 (tidak suka).

Kata kunci : bakso, tepung wortel, daging ayam

\section{PENDAHULUAN}

Bakso merupakan produk gel dari protein daging, baik daging sapi, ayam, ikan maupun udang (Mentari et al., 2016). Setelah dimasak bakso memiliki tekstur yang kenyal sebagai ciri spesifiknya. Bakso merupakan salah satu makanan yang sangat disukai dikalangan masyarakat, baik anak - anak maupun orang dewasa (Wodi et al., 2019). Selain rasanya yang enak, cara pembuatannya juga relatif mudah. Bakso yang telah dipasarkan secara luas adalah bakso yang dibuat dengan bahan dasar daging sapi atau ikan dengan campuran bahan lainnya seperti tepung tapioka sebagai bahan pengisi, dan garam, gula, lada, es batu, bawang merah dan bawang putih sebagai bumbu. Kualitas bakso bervariasi tergantung dari bahan baku yang ditambahkan, proporsi daging dan tepung dan pembuatannya. Bakso merupakan produk hasil olahan daging, dimana daging tersebut telah dihaluskan terlebih dahulu dan dicampur dengan bumbu-bumbu, tepung dan kemudian dibentuk seperti bola-bola kecil lalu direbus dalam air panas (Widyaningsih \& Murtini, 2006).

Produk olahan daging ini banyak dikenal masyarakat. Kualitas bakso dapat dipengaruhi oleh beberapa faktor, yaitu bahan pengisi, kadar air, lemak, dan protein bakso (Hairunnisa et al., 2016). Rasa merupakan faktor penentu daya terima konsumen terhadap produk pangan (Salman et al., 2018). Bakso tanpa pengawet memiliki masa simpan maksimal satu hari pada suhu kamar dan dua hari pada suhu dingin (Damiyati, 2007). Bakso merupakan bahan pangan yang mudah rusak karena bakso mengandung protein yang tinggi, memiliki kadar air yang tinggi, dan $\mathrm{pH}$ bakso netral (Arief et al., 2012; Chrismanuel et al., 2012). Bakso yang bermutu bagus dapat dibuat tanpa penambahan bahan kimia apapun. Standar mutu bakso daging dapat dilihat pada tabel 1. (Departemen bidang pendayagunaan dan pemasyarakatan ilmu pengetahuan dan teknologi, 2007).

Penelitian ini bertujuan untuk mengetahui pengaruh penambahan proporsi tepung wortel dan lama pendinginan terhadap kualitas mikrobiologi bakso daging ayam dan mengetahui proporsi tepung wortel terbaik yang ditambahkan pada bakso ayam terhadap kualitas mikrobiologi dan organoleptik.

\section{METODE}

Rancangan percobaan yang dilakukan dalam penelitian pembuatan bakso daging ayam dengan penambahan tepung wortel ini menggunakan Rancangan Acak Kelompok Faktorial (RAK Faktorial) yang terdiri dari 2 faktor dengan 3 kali ulangan yaitu :

faktor 1: lama pendinginan dengan 2 perlakuan (3 hari dan 5 hari). 
faktor 2: penambahan proporsi tepung wortel dengan 3 perlakuan $(0 \%, 25 \%, 50 \%, 75 \%)$.

Dengan perlakuan penambahan tepung wortel dengan formula sebagai berikut:

L1W0 = lama pendinginan 3 hari; tepung tapioka $100 \%$ : tepung wortel $0 \%$

L1W1 = lama pendinginan 3 hari; tepung tapioka $75 \%$ : tepung wortel $25 \%$

L1W2 = lama pendinginan 3 hari; tepung tapioka $50 \%$ : tepung wortel $50 \%$

L1W3 = lama pendinginan 3 hari; tepung tapioka $25 \%$ : tepung wortel $75 \%$

L2W0 = lama pendinginan 5 hari; tepung tapioka $100 \%$ : tepung wortel $0 \%$

L2W1 = lama pendinginan 5 hari; tepung tapioka $75 \%$ : tepung wortel $25 \%$

L2W2 = lama pendinginan 5 hari; tepung tapioka 50\% : tepung wortel 50\%

L2W3 = lama pendinginan 5 hari; tepung tapioka $25 \%$ : tepung wortel $75 \%$

Tabel 1. Desain eksperimen

\begin{tabular}{cccc}
\hline \multirow{2}{*}{ Perlakuan } & \multicolumn{3}{c}{ Ulangan } \\
\cline { 2 - 4 } & I & II & III \\
\hline L1W0 & U1 & U2 & U3 \\
L1W1 & U1 & U2 & U3 \\
L1W2 & U1 & U2 & U3 \\
L1W3 & U1 & U2 & U3 \\
L2W0 & U1 & U2 & U3 \\
L2W1 & U1 & U2 & U3 \\
L2W2 & U1 & U2 & U3 \\
L2W3 & U1 & U2 & U3 \\
\hline
\end{tabular}

\section{Bahan}

a. Bahan yang digunakan dalam pembuatan bakso ayam dan tepung wortel meliputi wortel (Daucus carrota L.) varietas Chantenay dari pasar Pandaan, tepung tapioka, $\mathrm{NaCl}$, daging ayam broiler dari pasar Pandaan, bumbu (bawang putih, bawang merah dan merica), air.

b. Bahan yang digunakan dalam analisa di Laboratorium meliputi Air destilasi, Plate Count Agar (Oxoid), Cromo Cult Agar (Merck), YGC Agar (Merck), Buffer Peptone Water (Merck).

\section{Alat}

1. Peralatan yang digunakan dalam pembuatan bakso meliputi alat penghancur (blender), pisau, panci, kompor, sendok, cawan timbang, timbangan analitik, wadah.

2. Peralatan yang digunakan dalam analisa di Laboratorium meliputi vortex (Barnstead), petridish steril (Biologix), botol Schott Duran 1000 liter, botol Schott Duran 500 liter, gelas ukur (Pyrex), erlenmeyer (Schott Duran), hot plate dan stirer (Cimarec), autoclave (Hirayama), waterbath (Memmert), Laminair Air Flow (Ultra Safe), pipet digital (Satorius) dan tip (biomeuriux), Thermometer (dekko), Inkubator (binder), plastic bag steril, $\mathrm{pH}$ Meter (Mettler Toledo), Coloni Counter (Stuart Scientific).

\section{Proses pembuatan bakso wortel}

Proses pembuatan bakso daging ayam yaitu persiapkan daging ayam segar yang telah dibersihkan dari lemak dan urat. Daging dicincang kecil-kecil untuk mempermudah penggilingan. Daging digiling sampai halus dengan penambahan es batu atau air es $15 \%$ dari berat daging yang digunakan. Tambahkan garam yodium 2,5\%. Pada proses pencampuran tambahkan tepung tapioka dan tepung wortel sesuai formula perlakuan L1W0, L1W1, L1W2, L1W3, L2W0, L2W1, L2W2, L2W3 dan bumbubumbu (bawang merah 2\%, bawang putih $2 \%$, merica/lada $0,5 \%$, dalam masing-masing 4 adonan/300 gr daging ayam, lalu semua bahan dicampur menjadi adonan yang homogen dan membentuk adonan bakso. Diamkan adonan selama 5 menit, dan kemudian bentuk bakso menjadi bulatan kecil. Kemudian rebus bakso pada suhu $100^{\circ} \mathrm{C}$ selam 5-10 menit dan tiriskan. Dinginkan bakso dengan suhu ruang dan lakukan analisa uji mutu $(\mathrm{pH}$, Total Plate Count, Total Coliform, Total Khamir dan Kapang) dan uji organoleptic terhadap rasa, warna, aroma dan tekstur bakso ayam.

\section{Analisa data}

Uji organoleptik dilakukan menggunakan metode hedonik dengan skala 1 (sangat tidak suka) sampai 5 (sangat suka). Pengujian dilakukan terhadap 25 panelis tidak terlatih. Panelis diminta menyatakan penilaiannya dari kesukaan terhadap aroma, 
rasa, warna dan tekstur pada kertas format yang telah disediakan. Analisis data uji organoleptik menggunakan Uji Friedman. Parameter Mikrobiologi yang diamati pada produk bakso wortel yaitu Nilai $\mathrm{pH}$ (Manual alat $\mathrm{pH}$ Meter Mettler Toledo), Total Plate Count (Sudarmaji et al., 1984), Total Coliform (Sudarmaji et al., 1984), Total Khamir dan Kapang (Sudarmaji et al., 1984). Penelitian uji Mikrobiologi dianalisa dengan uji $\mathrm{F}$ dan jika terdapat perbedaan dianalisa dengan uji tuckey. Perlakuan terbaik menurut uji organoleptik dianalisa menggunakan metode indeks efektifitas de Garmo et al., (1998) yang dimodifikasi oleh Susrini (2003) dan Perlakuan terbaik menurut uji Mikrobiologi dianalisa menggunakan metode Zeleny (1982).

\section{HASIL DAN PEMBAHASAN}

\section{Uji mikrobiologi \\ Nilai pH}

Berdasarkan

hasil penelitian didapatkan rata-rata nilai $\mathrm{pH}$ antara 6,42 6,55. Data hasil pengujian nilai $\mathrm{pH}$ dapat dilihat pada tabel 2 .

Tabel 2. Rata-rata nilai $\mathrm{pH}$

\begin{tabular}{cc}
\hline Perlakuan & Rata-rata pH \\
\hline L1W0 & $6,45 \mathrm{c}$ \\
L1W1 & $6,55 \mathrm{ab}$ \\
L1W2 & $6,54 \mathrm{ab}$ \\
L1W3 & $6,55 \mathrm{a}$ \\
L2W0 & $6,42 \mathrm{c}$ \\
L2W1 & $6,47 \mathrm{bc}$ \\
L2W2 & $6,48 \mathrm{abc}$ \\
L2W3 & $6.52 \mathrm{abc}$ \\
\hline
\end{tabular}

Keterangan: Nilai rata-rata yang diikuti oleh huruf yang sama tidak berpengaruh nyata menurut Uji Tuckey

Penambahan prosentase tepung wortel tidak begitu berpengaruh terhadap $\mathrm{pH}$ bakso ayam tetapi lama penyimpanan yang semakin bertambah menyebabkan $\mathrm{pH}$ bakso ayam menurun sehingga akan meningkatkan Total Plate Count pada bakso ayam. Soeparno (1998), menyatakan bahwa pertumbuhan mikroorganisme dipengaruhi oleh suhu dan pH. Menurut Lawrie (1995), bahwa penurunan nilai rata-rata $\mathrm{pH}$ penyimpanan 0 hari ke 12 hari aktivitas pertumbuhan mikroba sangat cepat, sehingga $\mathrm{pH}$ bakso mengalami penurunan. $\mathrm{pH}$ dipengaruhi oleh kadar air pada produk. Hal ini sesuai dengan pendapat Nurwantoro dkk. (1997), menyatakan bahwa kadar air suatu bahan berbanding lurus dengan $\mathrm{pH}$, dimana semakin menurun kadar air maka $\mathrm{pH}$ pun akan semakin rendah. Menurut Varnam et al. (1995), penurunan $\mathrm{pH}$ disebabkan karena adanya bakteri asam laktat alami dalam bakso yang mampu melakukan aktivitas fermentasi dalam mengubah glikogen dan menghasilkan asam laktat. Sesuai dengan pendapat Adams \& Moss (2000) dan Tortora et al. (2001), menyatakan bahwa kelompok dari Psychrophilles (Obligatepsychrophilles) dan Psychrotrops (Facutativepsychrophilles) mampu hidup pada suhu -5 sampai dengan $35{ }^{\circ} \mathrm{C}$

\section{Total plate count}

Berdasarkan hasil penelitian didapatkan rata-rata total plate count antara $0,12 \log 10^{4} \mathrm{cfu} / \mathrm{gr}-2,43 \log 10^{4} \mathrm{cfu} / \mathrm{gr}$ Data hasil pengujian TPC dapat dilihat pada Tabel 3

Tabel 3. Rata-rata total plate count

\begin{tabular}{cc}
\hline Perlakuan & Rata-rata $\left(\log 10^{\mathbf{4}} \mathbf{c f u} / \mathbf{g r}\right)$ \\
\hline L1W0 & $2,05 \mathrm{a}$ \\
L1W1 & $1,43 \mathrm{bc}$ \\
L1W2 & $0,97 \mathrm{c}$ \\
L1W3 & $0,12 \mathrm{~d}$ \\
L2W0 & $2,43 \mathrm{a}$ \\
L2W1 & $1,73 \mathrm{ab}$ \\
L2W2 & $1,29 \mathrm{bc}$ \\
L2W3 & $0,13 \mathrm{~d}$ \\
\hline
\end{tabular}

Keterangan: Nilai rata-rata yang diikuti oleh huruf yang sama tidak berpengaruh nyata menurut $\mathrm{Uji}$ Tuckey

Hasil menunjukkan bahwa jumlah Total Plate Count yang terdapat dalam bakso ayam akan bertambah seiring bertambahnya waktu lama penyimpanan. Hal ini sesuai dengan pendapat Fardiaz (1992), bahwa pengaruh lama penyimpanan memberikan pengaruh peningkatan jumlah bakteri di dalam bakso ayam yang disebabkan oleh 
penurunan $\mathrm{pH}$ dan suhu penyimpanan. Semakin banyak prosentase tepung wortel yang ditambahkan maka Total Plate Count bakso ayam mengalami penurunan yang signifikan. Hal ini sesuai pendapat Abdillah dan Fatimah (2006), wortel mengandung antioksidan yakni $\beta$-karoten yang dapat mencegah atau menghambat fermentasi terhadap makanan yang disebabkan oleh mikroorganisme.

\section{Total coliform}

Berdasarkan hasil penelitian didapatkan rata-rata total coliform antara $0,03 \log 10^{2} \mathrm{cfu} / \mathrm{gr}-2,1 \log 10^{2} \mathrm{cfu} / \mathrm{gr}$ Data hasil pengujian total coliform dapat dilihat pada Tabel 4.

Tabel 4. Rata-rata total coliform

\begin{tabular}{cc}
\hline Perlakuan & Rata-rata $\left(\log 10^{2} \mathbf{c f u} / \mathbf{g r}\right)$ \\
\hline L1W0 & $1,65 \mathrm{a}$ \\
L1W1 & $1,15 \mathrm{bc}$ \\
L1W2 & $0,66 \mathrm{~d}$ \\
L1W3 & $0,03 \mathrm{e}$ \\
L2W0 & $2,1 \mathrm{a}$ \\
L2W1 & $1,47 \mathrm{ab}$ \\
L2W2 & $1,01 \mathrm{c}$ \\
L2W3 & $0,05 \mathrm{e}$ \\
\hline
\end{tabular}

Keterangan: Nilai rata-rata yang diikuti oleh huruf yang sama tidak berpengaruh nyata menurut $\mathrm{Uji}$ Tuckey

Hasil menunjukkan bahwa jumlah Total Coliform yang terdapat dalam bakso ayam mengalami peningkatan secara seiring bertambahnya waktu lama penyimpanan. Akan tetapi semakin banyak prosentase tepung wortel yang ditambahkan maka nilai Total Coliform bakso ayam mengalami penurunan yang signifikan. Hal ini sesuai pendapat Abdillah dan Fatimah (2006), wortel mengandung antioksidan yakni $\beta$ karoten yang dapat mencegah atau menghambat fermentasi terhadap makanan yang disebabkan oleh mikroorganisme. Wortel mengandung senyawa antioksidan yang berasal dari jenis non enzimatik, terdiri dari mikronutrien berupa vitamin, beberapa vitamin yang terdapat pada wortel berfungsi sebagai antioksidan antara lain vitamin $\mathrm{C}$ dan $\beta$-karoten (McDermott, 2000).

\section{Total khamir dan kapang}

Berdasarkan hasil penelitian didapatkan rata-rata Total Khamir dan Kapang antara $0,17 \quad \log 10^{2} \mathrm{cfu} / \mathrm{gr} \quad-3.3$ $\log 10^{2} \mathrm{cfu} / \mathrm{gr}$ Data hasil pengujian total khamir dan kapang dapat dilihat pada tabel 5.

Tabel 5. Rata-rata total khamir dan kapang

\begin{tabular}{cc}
\hline Perlakuan & Rata-rata(log10 $\left.\mathbf{2}^{2} \mathbf{c f u} / \mathbf{g r}\right)$ \\
\hline L1W0 & $3,1 \mathrm{a}$ \\
L1W1 & $2,33 \mathrm{a}$ \\
L1W2 & $1,13 \mathrm{~b}$ \\
L1W3 & $0,17 \mathrm{c}$ \\
L2W0 & $3,3 \mathrm{a}$ \\
L2W1 & $2,77 \mathrm{a}$ \\
L2W2 & $1,37 \mathrm{~b}$ \\
L2W3 & $0,27 \mathrm{c}$ \\
\hline
\end{tabular}

Keterangan: Nilai rata-rata yang diikuti oleh huruf yang sama tidak berpengaruh nyata menurut $\mathrm{Uji}$ Tuckey

Hasil menunjukkan bahwa jumlah Total Khamir dan Kapang yang terdapat dalam bakso ayam mengalami peningkatan secara seiring bertambahnya waktu lama penyimpanan. Akan tetapi semakin banyak prosentase tepung wortel yang ditambahkan maka nilai Total Khamir dan Kapang bakso ayam mengalami penurunan yang signifikan. Hal ini sesuai pendapat Abdillah dan Fatimah (2006), wortel mengandung antioksidan yakni $\beta$-karoten yang dapat mencegah atau menghambat fermentasi terhadap makanan yang disebabkan oleh mikroorganisme. Menurut Nuansa (2011), bahwa extrak wortel dapat menjadi antioksidan pada bakso untuk mencegah dan menghambat ketengikan yang diakibatkan udara dan mikroorganisme.

\section{Uji organoleptik}

Uji organoleptik yang dilakukan melputi rasa, aroma, warna dan tekstur. Uji organoleptik ini dilakukan oleh 25 panelis, Panelis diminta menyatakan penilaiannya dari kesukaan terhadap rasa, aroma, warna dan tekstur pada kertas format yang telah disediakan. 


\section{Uji organoleptik rasa}

Hasil uji organoleptik menunjukkan bahwa rata-rata ranking kesukaan terhadap rasa dari perlakuan antara persentase perbedaan proporsi tepung wortel berkisar antara 2,36 (tidak suka) sampai 3,0 (netral). Hasil pengujian organoleptik terhadap rasa bakso wortel dapat dilihat pada Gambar 1

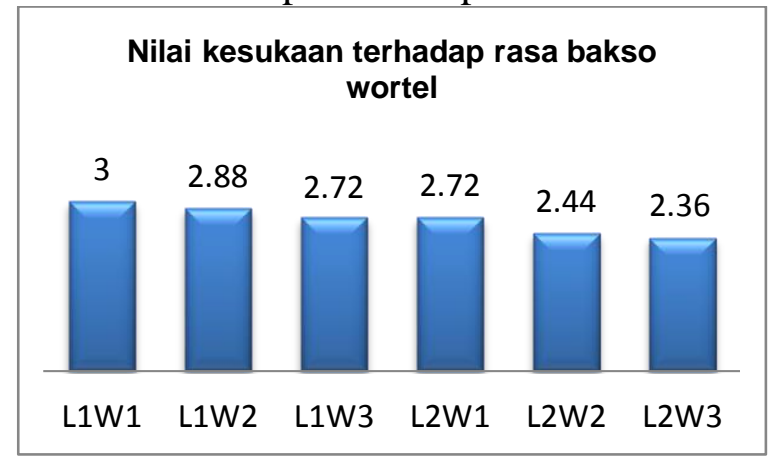

Gambar 1. Histogram rata-rata kesukaan rasa bakso wortel panelis terhadap rasa bakso wortel.

Rataan organoleptik rasa yang suka menurut 25 panelis adalah perlakuan L1W1 (lama pendinginan 3 hari; tepung tapioka $75 \%$ : tepung wortel 25\%) dan rataan organoleptik rasa yang tidak suka menurut 25 panelis adalah perlakuan L2W3 (lama pendinginan 5 hari; tepung tapioka $25 \%$ : tepung wortel $75 \%$ ). Kriteria mutu sensori bakso daging adalah rasa lezat, enak, rasa daging dominan, rasa bumbu cukup menonjol tetap tidak berlebihan dan tidak terdapat rasa asing yang mengganggu (Sinaga \& Suhaidi, 2007; Wibowo, 2005). Penambahan tepung wortel yang tidak begitu disukai oleh panelis dikarenakan rasa wortel yang terasa dominan di bandingkan dengan daging ayam.

\section{Uji organoleptik aroma}

Hasil uji organoleptik menunjukkan bahwa rata-rata ranking kesukaan terhadap aroma dari perlakuan antara persentase perbedaan proporsi tepung wortel berkisar antara 2,92 (netral) sampai 3,96 (suka). Hasil pengujian organoleptik terhadap aroma bakso wortel dapat dilihat pada Gambar 2.

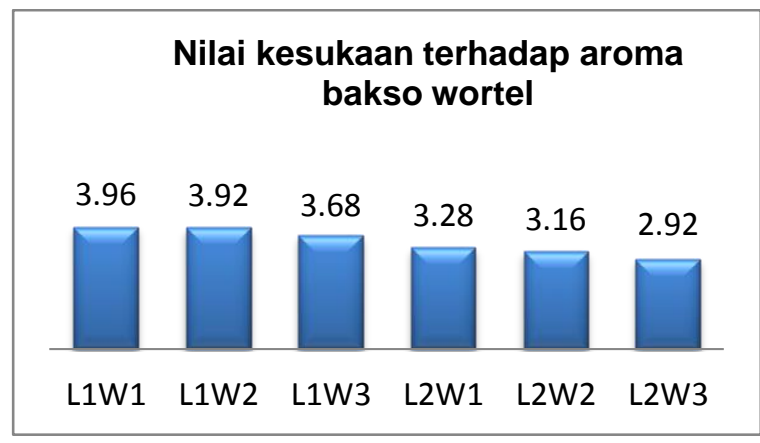

Gambar 2. Histogram rata-rata kesukaan aroma bakso wortel panelis terhadap aroma bakso wortel.

Rataan organoleptik aroma yang disukai menurut 25 panelis adalah perlakuan L1W1 (lama pendinginan 3 hari; tepung tapioka $75 \%$ : tepung wortel $25 \%$ ) dan rataan organoleptik rasa yang tidak disukai menurut 25 panelis adalah perlakuan L2W3 (lama pendinginan 5 hari; tepung tapioka $25 \%$ : tepung wortel $75 \%$. Hal ini disebabkan aroma langu yang khas dari wortel masih terasa. Menurut (Sinaga \& Suhaidi, 2007; Wibowo, 2005) kriteria mutu sensoris bakso daging yaitu bau khas daging segar rebus dominan, tanpa bau tengik, masam, basi atau busuk, bau bumbu-bumbu cukup tajam. Menurut Fellows (2009) wortel memiliki enzim lipoksisase yang menyebabkan aroma langu.

\section{Uji organoleptik warna}

Hasil uji organoleptik menunjukkan bahwa rata-rata ranking kesukaan terhadap warna dari perlakuan antara persentase perbedaan proporsi tepung wortel berkisar antara 2,16 (tidak suka) sampai 3,64 (suka). Hasil pengujian organoleptik terhadap warna bakso wortel dapat dilihat pada Gambar 3.

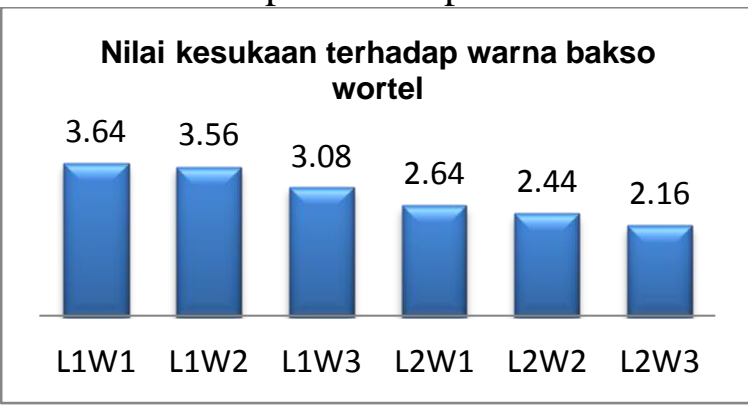

Gambar 3. Histogram rata-rata kesukaan warna bakso wortel panelis terhadap warna bakso wortel. 
Rataan organoleptik warna yang disukai menurut 25 panelis adalah perlakuan L1W1 (lama pendinginan 3 hari; tepung tapioka $75 \%$ : tepung wortel $25 \%$ ) dan rataan organoleptik warna yang tidak disukai menurut 25 panelis adalah perlakuan L2W3 (lama pendinginan 5 hari; tepung tapioka $25 \%$ : tepung wortel $75 \%$. Hal ini disebabkan warna kuning pada bakso ayam akibat dari penambahan tepung wortel digunakan sebagai daya tarik bakso sehingga lebih disukai oleh para panelis. Beberapa panelis juga berkomentar bahwa warna kuning sebagai inovasi baru dengan pewarna alami dan daya tarik tersendiri pada produk bakso. Selama ini bakso daging belum ada yang berwarna kuning, hanya berwarna putih cerah. Warna merupakan komponen yang sangat penting dalam menentukan kualitas atau derajat penerimaan suatu bahan pangan (Purukan et al., 2013). Warna kuning itu sendiri berasal dari pigmen karotenoid yang terdapat pada tepung wortel. Pigmen karotenoid menyebabkan jaringan berwarna kuning, sehingga intensitas warna kuning dapat menjadi indicator umum bagi kandungan vitamin $\mathrm{A}$. wortel merupakan sayuran sumber provitamin A, yang memiliki kandungan karoten yang tinggi. Karoten merupakan pigmen berwarna kuning dan orange pada buah dan sayur (Ali et al., 2003).

\section{Uji organoleptik tekstur}

Hasil uji organoleptik menunjukkan bahwa rata-rata ranking kesukaan terhadap tekstur dari perlakuan antara persentase perbedaan proporsi tepung wortel berkisar antara 2,16 (tidak suka) sampai 3,64 (suka). Hasil pengujian organoleptik terhadap tekstur bakso wortel dapat dilihat pada Gambar 4.

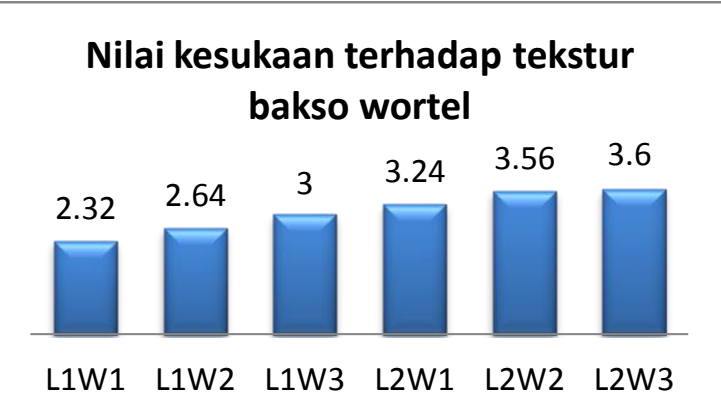

Gambar 4. Histogram rata-rata kesukaan tekstur bakso wortel panelis terhadap tekstur bakso wortel.

Rataan organoleptik tekstur yang disukai menurut 25 panelis adalah perlakuan L2W3 (lama pendinginan 5 hari; tepung tapioka $25 \%$ : tepung wortel $75 \%$ ) dan rataan organoleptik warna yang tidak disukai menurut 25 panelis adalah L1W1 (lama pendinginan 3 hari; tepung tapioka $75 \%$ : tepung wortel 25\%). Menurunnya tingkat kesukaan panelis terhadap organoleptik tekstur juga disebabkan oleh adanya kandungan air dan protein pada tepung wortel yang sangat berpengaruh terhadap tingkat kekenyalan bakso. Seiring dengan semakin banyaknya tepung wortel yang ditambahkan maka tingkat kekenyalan dari bakso ayam juga semakin besar. Offer dan Knight (1988) menyatakan bahwa jumlah air yang terkandung dalam bahan pangan berpengaruh terhadap tekstur, juiceness dan tingkat kekerasan

\section{Perlakuan terbaik uji mikrobiologi}

Penentuan perlakuan terbaik menggunakan metode Zeleny pada parameter uji Mikrobiologi yang meliputi nilai pH, Total Plate Count, Total Coliform, Total Khamir dan Kapang. Hasil perhitungan menunjukkan perlakuan terbaik terdapat pada perlakuan L1W3 (lama pendinginan 3 hari; tepung tapioka $25 \%$ : tepung wortel $75 \%)$. Dengan ketentuan mikrobiologi $\mathrm{pH}$ (6,55), Total Plate Count $(0,12$ $\left.\log 10^{2} \mathrm{cfu} / \mathrm{gr}\right), \quad$ Total Coliform $(0,03$ $\left.\log 10^{2} \mathrm{cfu} / \mathrm{gr}\right)$, Total Khamir dan Kapang $\left(0,17 \log 10^{2} \mathrm{cfu} / \mathrm{gr}\right)$. 


\section{Perlakuan terbaik uji organoleptik}

Penentuan perlakuan terbaik untuk parameter organoleptik yang meliputi rasa, aroma, warna dan tekstur dengan menggunakan metode indeks efektifitas yaitu dengan menentukan bobot untuk setiap parameter, menentukan nilai efektifitas (NE) dan nilai produk (NP) yang selanjutnya nilai produk pada setiap parameter uji organoleptik dijumlah untuk mendapatkan perlakuan terbaik menurut De Garmo et al., (1984) yang dimodifikasi oleh Susrini (2003) Berdasarkan kualitas organoleptik bakso ayam, perlakuan terbaik yaitu pada perlakuan L1W1 (lama pendinginan 3 hari; tepung tapioka $75 \%$ : tepung wortel $25 \%$ ). Dengan ketentuan organoleptik rasa 3(suka), aroma 3,96 (suka), warna 3,64 (suka) dan tekstur 2,32 (tidak suka). Analisis organoleptik akan memberikan keyakinan terhadap pengambilan keputusan pentingyang sangat bergantung pada data pengujian kualitas sensori produk (Setyaningsih et al., 2014).

\section{KESIMPULAN}

1. Hasil penelitian menunjukkan bahwa penambahan proporsi tepung wortel dan lama pendinginan terhadap kualitas Mikrobiologi berbeda nyata terhadap nilai $\mathrm{pH}$, Total Plate Count, Total Coliform, Total Khamir dan Kapang serta organoleptik (rasa, aroma, warna dan tekstur).

2. Perlakuan terbaik menurut hasil uji laboratorium dengan menggunakan metode Zeleny (1982) yaitu pada perlakuan L1W3 (lama pendinginan 3 hari dan tepung tapioka $25 \%$ : tepung wortel 75\%) dengan ketentuan mikrobiologi $\mathrm{pH}$ (6,55), Total Plate Count $\left(0,12 \log 10^{2} \mathrm{cfu} / \mathrm{gr}\right)$, Total Coliform (0,03 $\left.\log 10^{2} \mathrm{cfu} / \mathrm{gr}\right)$, Total Khamir dan Kapang $\left(0,17 \quad \log 10^{2} \mathrm{cfu} / \mathrm{gr}\right), \quad$ dan organoleptik rasa 2,72 (tidak suka), aroma 2,92 (tidak suka), warna 3,08 (suka) dan tekstur 3 (suka).

3. Perlakuan terbaik menurut hasil uji organoleptik dengan menggunakan Indeks
Efektifitas De Garmo et al., (1984) yang dimodifikasi oleh Susrini (2003) yaitu pada perlakuan L1W1 (lama pendinginan 3 hari dan tepung tapioka $75 \%$ : tepung wortel 25\%) dengan ketentuan mikrobiologi $\mathrm{pH}(6,55)$, Total Plate Count (1,43 $\left.\log 10^{2} \mathrm{cfu} / \mathrm{gr}\right)$, Total Coliform $\left(1,15 \log 10^{2} \mathrm{cfu} / \mathrm{gr}\right)$, Total Khamir dan Kapang (2,33 $\left.\log 10^{2} \mathrm{cfu} / \mathrm{gr}\right), \quad$ dan organoleptik rasa 3(suka), aroma 3,96 (suka), warna 3,64 (suka) dan tekstur 2,32 (tidak suka).

\section{SARAN}

1. Perlu dilakukan penelitian lanjutan tentang kadar $\beta$-karoten bakso ayam dengan penambahan proporsi tepung wortel yang berbeda.

2. Perlu dilakukan penelitian lanjutan tentang daya simpan bakso ayam dengan penambahan prosentase tepung wortel yang berbeda.

\section{UCAPAN TERIMA KASIH}

Pada kesempatan ini penulis mengucapkan puji syukur kehadirat Allah SWT dan mengucapkan terima kasih kepada Dosen Pembimbing dan Para Dosen Ilmu dan Teknologi Pangan Fakultas Pertanian Universitas Yudharta,serta teman-teman yang telah memberikan saran dan masukan sehingga dapat menyelesaikan penelitian ini.

\section{DAFTAR PUSTAKA}

Abdillah, \& Fatimah. (2006). Penambahan tepung wortel dan karagenan untuk meningkatkan kadar serat pangan pada nugget ikan nila (Oreochromis Sp.) [Tugas Akhir]. IPB University.

Adams, M. R., \& Moss, M. O. (2000). The microbiology of food preservation. In Food microbiology (pp. 65-120).

Ali, N. B. V., Rahayu, E., \& Sunarjono, H. (2003). Wortel dan lobak. Jakata: Penebar Swadaya.

Arief, H. S., Pramono, Y. B., \& Bintoro, V. P. (2012). Pengaruh edible coating 
dengan konsentrasi berbeda terhadap kadar protein, daya ikat air dan aktivitas air bakso sapi selama masa penyimpanan. Animal Agriculture Journal, 1(2), 100-108.

Chrismanuel, A., Pramono, Y. B., \& Setiani, B. E. (2012). Efek Pemanfaatan Karaginan Sebagai Edible Coating Terhadap pH, Total Mikroba Dan H2S Pada Bakso Selama Penyimpanan 16 Jam. Animal Agriculture Journal, 1(2), 286-292.

DeGarmo, E. D., Sullivan, W. G., \& Canada, J. R. (1998). Engineering economy.

Departemen bidang pendayagunaan dan pemasyarakatan ilmu pengetahuan dan teknologi. (2007). Bakso. Bakso. http://www.ristek.co.id.

Fardiaz, S. (1992). Mikrobiologi pangan 1. Jakarta: PT. Gramedia.

Fellows, P. J. (2009). Food processing technology: Principles and practice. Elsevier.

Hairunnisa, O., Sulistyowati, E., \& Suherman, D. (2016). Pemberian kecambah kacang hijau (tauge) terhadap kualitas fisik dan uji organoleptik bakso ayam. Jurnal Sain Peternakan Indonesia, 11(1), 39-47.

Lawrie, R. A. (1995). Ilmu daging. Jakarta: Universitas Indonesia Press.

McDermott, J. H. (2000). Antioxidant nutrient: Current diet recommendations and research update. Journal of the American Pharmaceutical Association (1996), 40(6), 785-799. https://doi.org/10.1016/S10865802(16)31126-3

Mentari, R., Anandito, R. B. K., \& Basito, B. (2016). Formulasi daging analog berbentuk bakso berbahan kacang merah (phaseolus vulgaris) dan kacang kedelai (Glycine max). Jurnal Teknosains Pangan, 5(3).

Nuansa. (2011). Bercocok tanam wortel. Bandung: Fakultas Teknologi Industri Pertanian.

Offer, G., \& Knight, P. (1988). The structural basis of WHC in meat. Elsevier Applied Science.
Purukan, O. P., Mamuaja, C. F., Mandey, L. C., \& Mamahit, L. P. (2013). Pengaruh penambahan bubur wortel (Daucus carrota) dan tepung tapioka terhadap sifat fisikokimia dan sensoris bakso ikan gabus (Ophiocephalus striatus). COCOS, 2(4), 1-10.

Salman, Y., Syainah, E., \& Rezkiah, R. (2018). Analisis Kandungan Protein, Zat Besi dan Daya Terima Bakso Ikan Gabus dan Daging Sapi. Jurnal Kedokteran Dan Kesehatan, 14(1), 6373.

Setyaningsih, D., Apriyantono, A., \& Sari, M. P. (2014). Analisis Sensori untuk industri pangan dan argo. Bogor: PT Penerbit IPB Press.

Sinaga, H., \& Suhaidi, I. (2007). Pembuatan bakso daging sapi dengan penambahan kitosan [Tugas Akhir]. Departemen Teknologi Pertanian Sumatra Utara.

Soeparno. (1998). Ilmu dan teknologi daging. Yogyakarta: Gadjah Mada University Press.

Sudarmaji, S., Haryono, B., \& Suhardi. (1984). Prosedur analisa untuk bahan makanan dan pertanian. Liberty.

Tortora, G. F., Berbell, \& Christine, C. (2001). Microbiology an Introdution. San Francisco: Addison Wesley Longman.

Varnam, A., Sutherland, J. M., \& Sutherland, J. P. (1995). Meat and meat products: Technology, chemistry and microbiology (Vol. 3). London: Springer Science \& Business Media.

Wibowo, S. (2005). Pembuatan bakso ikan dan bakso daging. Jakarta: Penebar Swadaya.

Widyaningsih, T. D., \& Murtini, E. S. (2006). Alternatif pengganti formalin pada produk pangan. Surabaya: Trubus Agrisarana.

Wodi, S. I. M., Cahyono, E., \& Kota, N. (2019). Analisis mutu bakso ikan home industri dan komersil di Babakan Raya Bogor. Jurnal FishtecH, 8(1), 7-11. 